\title{
Growing Legumes in Orchard Alleys as an Internal Nitrogen Source
}

\author{
David Granatstein \\ Center for Sustaining Agriculture and Natural Resources, Washington State \\ University, Wenatchee, WA 98801
}

\author{
Joan R. Davenport ${ }^{1}$ \\ Irrigated Agriculture Research and Extension Center, Washington State \\ University, 24106 N. Bunn Road, Prosser, WA 99350
}

\section{Elizabeth Kirby \\ Center for Sustaining Agriculture and Natural Resources, Washington State University, Wenatchee, WA 98801}

Additional index words. apple, alfalfa, clover, trefoil, direct seeding, ion exchange probes

\begin{abstract}
The drive alley in modern apple (Malus $\times$ domestica Bork.) orchards often receives enough light to grow plants other than the typical perennial grass cover. By planting leguminous species in this area, it is possible to produce a portion of the nitrogen needs of the orchard by mowing the vegetation and blowing it onto the tree row where it mineralizes and releases available $\mathbf{N}$ over the tree roots. Four perennial legume species [alfalfa (Medicago sativa L.), ladino white clover (Trifolium repens L.), birdsfoot trefoil (Lotus corniculatus L.), kura clover (Trifolium ambiguum $\mathbf{L}$.)] were compared with the resident grass cover crop in a mature apple orchard. All legumes were direct-seeded into the alley to avoid any soil disturbance and were successfully established. Legume biomass and tissue $\mathbf{N}$ were monitored, along with biweekly monitoring of tree row soil nitrogen with both soil sampling and ion exchange resins using Plant Root Simulator ${ }^{\circledR}$ probes. Four mowings of alfalfa contained $\approx 43 \mathrm{~kg}$ total $\mathrm{N} / \mathrm{ha}$ that was added to the tree row during the second season (2009), with a dry matter $C: N$ of 10.8. Economically, legume nitrogen appears to be less expensive than other sources of organic $N$ and may be cost competitive with synthetic fertilizer $N$ when prices are high.
\end{abstract}

Modern high density apple orchards have altered canopy architecture by shifting to dwarfing trees with a more two-dimensional architecture and less dense canopies. These changes improve light distribution and spray coverage, produce more uniform fruit, and enhance labor safety and productivity (Barritt, 1992). In addition, they typically result in far more light reaching the orchard floor, which creates the opportunity to grow plants on the orchard floor for specific purposes, such as flowering species to support beneficial insects or legumes for nitrogen fixation (Granatstein and Sanchez, 2009). This could occur in the tree row, as a "living mulch" or in the drive alley, where the legume biomass could be mowed in place, mowed, and blown on to the tree row, or incorporated into the soil (Mullinix and Granatstein, 2011). In the Pacific Northwest United States, nitrogen is the macronutrient most often needed on a

Received for publication 17 May 2017. Accepted for publication 11 July 2017.

Funding support was provided by the USDA Organic Cropping Research Special Grant.

Thanks to Warren Morgan, Harry Huntley, and Amos Kukes for hosting the trial and providing orchard management. Thanks to Jeff Lunden, Tanya Winkler, Anne Guerin, Awais Sial, Rachel Miller, and Cindy Kahn for field and laboratory support.

${ }^{1}$ Corresponding author. E-mail: jdavenp@wsu.edu. yearly basis to sustain fruit production (Neilsen and Neilsen, 2003). Leguminous species can be planted in the drive alley to produce a significant portion of the nitrogen needs of the orchard (Goh and Ridgen, 1995; Sanchez et al., 2006) by mowing the vegetation and blowing it onto the tree row where it mineralizes and releases available $\mathrm{N}$ over the tree roots (Marsh et al., 1996). This may be particularly attractive for organic producers who do not have access to low-cost organic nitrogen sources (Mullinix and Granatstein, 2011) as legume nitrogen is normally the least expensive organic $\mathrm{N}$ source per dry kilogram N. Biologically fixed nitrogen also has a smaller carbon footprint than synthetic $\mathrm{N}$ which is commonly made from natural gas using considerable energy (Camargo et al., 2013). Growers who have used or are currently using legumes in orchards normally till the soil to prepare a seedbed and then mechanically incorporate the legume biomass into the soil later in the season (Proebsting, 1958). This approach disturbs the soil, potentially accelerating soil carbon loss, increasing weed seed germination, and damaging surface tree roots. Direct seeding equipment has been developed for a variety of cropping systems and can be adapted for use in orchards, thus avoiding these problems.

The objectives of the study were to 1 ) evaluate the potential of four different legume species to produce plant biomass and add nitrogen to the tree row; and 2) monitor how much nitrogen from the legume was mineralized in the tree row soil using a "mow and blow" system. The study was not designed to measure or estimate nitrogen fixation. The target audience for the research was organic growers, for whom nitrogen inputs can represent a substantial cost; however, the system would be useful to any grower if it were cost competitive with their current practice.

\section{Materials and Methods}

The trial was established in a mature (15 year old) 'Gala'/M.26 apple orchard near Quincy, WA (lat. $47^{\circ} 13.216^{\prime}$, long. $\left.119^{\circ} 57.871^{\prime}\right)$, on a Shano silt loam soil (coarse-silty, mixed, superactive, mesic Xeric Haplocambid). Tree spacing was $1.6 \times$ $4.7 \mathrm{~m}$. All plots received the same management (pest control, pruning, thinning, and fertilization) other than the drive alley cover crop treatments. Nitrogen fertilizer (as $\mathrm{CaNO}_{3}$ ) was broadcast on the tree row of all plots each spring (24 Mar. 2009 and 20 May 2010) at a rate of $22.5 \mathrm{~kg} \mathrm{~N} / \mathrm{ha}$ as part of regular management. A urea application (44 $\mathrm{kg} \mathrm{N} / \mathrm{ha}$ ) was made on 22 Sept. 2008 in the tree row. Before planting the legume treatments, a $1.3 \mathrm{~m}$ strip in the middle of the grass drive alley was treated with glyphosate herbicide (1.66 kg a.i. per applied ha in 182 $\mathrm{L} \cdot \mathrm{ha}^{-1}$ water) on 17 Apr. 2008 to kill the existing vegetation. On 19 May 2008, four different perennial legumes ('Radiant' alfalfa, 'Norcen' birdsfoot trefoil, 'Jumbo' ladino white clover, and kura clover) were direct-seeded into the $1.3 \mathrm{~m}$ strip using a Truax Flex-II no-till grass drill (Truax Co., New Hope, MN) with six drill rows at 20 -cm spacing. Seeding rates $\left(\mathrm{kg} \cdot \mathrm{ha}^{-1}\right)$ were as follows: alfalfa and birdsfoot trefoil, 33.7; ladino white clover, 22.5; kura clover, 26.9. Seeds were treated with the appropriate rhizobial inoculum just before planting (Sinorhizobium meliloti for alfalfa, Rhizobium leguminosarum bv. trifolii for the clovers, and Mesorhizobium loti for trefoil). The orchard block was irrigated by undertree microsprinklers that watered the entire orchard floor.

Each plot consisted of a tree row and the adjacent two drive alleys (297 $\mathrm{m}$ length). A control plot with the resident grass alley vegetation was included. The design was a randomized complete block with four replications and five treatments (the four legume species plus the resident grass).

Plots were mowed at a $20 \mathrm{~cm}$ height on 26 June 2008 to control weeds. On $27 \mathrm{Aug}$. 2008 , all plots were mowed at $\approx 5-8 \mathrm{~cm}$ height with a mower designed to blow the cut vegetation onto the tree row on each side of the alley (mow and blow) through chutes on each side of the mower (Bush Hog 3210 rotary mower; Bush Hog Inc., Selma, AL). Mow and blow operations were subsequently conducted on 29 May, 3 July, 20 Aug., and 1 Oct. in 2009, and on 17 June, 21 July, 25 Aug., and 27 Sept. in 2010. Rodent activity 
was not quantitatively monitored but qualitative (observation) monitoring was done during each orchard visit. No tree girdling or increased signs of rodent activity were observed.

In both 2009 and 2010, the legume stands in the planted strip and the control grass alleys were evaluated on four dates, one to three days before each mowing, by measuring percent cover of the legume, grass, weeds, and bare ground using a $1-\mathrm{m}$ pointintersect wire at three subsample locations per plot. Plant biomass in the planted strip or control grass alley was collected by clipping vegetation inside a $0.25 \mathrm{~m}$ square at $\approx 5 \mathrm{~cm}$ above the ground from three subsamples per plot. Subsamples were pooled and mixed, dried at $45{ }^{\circ} \mathrm{C}$ for three days, and weighed for dry matter. A subsample was ground to $2 \mathrm{~mm}$ with a Wiley Mill (Thomas Scientific, Swedesboro, NJ) and analyzed for total N (Yeomans and Bremner, 1991) by dry combustion on an Elementar CNS analyzer (Elementar, Mt. Laurel, NJ). Biomass production was calculated by converting the grams per sampling area to $\mathrm{kg} \cdot \mathrm{ha}^{-1}$ and then multiplying by the fraction of the hectare that the legume stand represented ( 0.16 for grass, alfalfa, trefoil, kura clover, 0.18 for ladino clover). This was generally slightly less than the distance between the insides of the tractor tires $(90 \mathrm{~cm})$. The $\mathrm{N}$ content of the biomass was calculated by multiplying the biomass dry matter per hectare of orchard by the percent tissue $\mathrm{N}$ for that sample date. Biomass dry matter for all cuttings in a year was added together to report total seasonal biomass.

Tree nitrogen status was evaluated by collecting 30 leaves per plot from chestheight midterminal shoots on 10 randomly selected trees per plot on 23 July 2009 and 28 July 2010. Leaves were washed twice in deionized water, dried at $45{ }^{\circ} \mathrm{C}$, and ground and analyzed with the same procedures as for the legume biomass. In addition, a complete mineral analysis of leaf samples was done in 2010 by Soiltest Farm Consultants (Moses Lake, WA) using dry combustion for $\mathrm{N}$ analysis and inductively coupled plasma emission spectrometry (Soltanpour et al., 1996) for all other elements.

To look at initial amounts of plant available $\mathrm{N}$ in the surface soil, soil samples were collected using a 2.54-cm I.D. soil probe (AMS, American Falls, ID) on 11 Apr. 2008 before treatment, composited for each block, with separate samples for the tree row and drive alley at both $0-15$ and $15-30 \mathrm{~cm}$ depths. Samples were extracted using $1 \mathrm{M}$ $\mathrm{KCl}$ and analyzed for ammonium and nitrate N (Mulvaney, 1996) by direct injection colorimetry on an EasyChem Analyzer (Systea Scientific, Chicago, IL). Soils were sampled by individual plot at 0,7 , and $27 \mathrm{~d}$ after mow and blow in Sept. 2008. Starting in 2009, soil samples were analyzed for nitrate only as ammonium concentrations in this and similar studies (Bair et al., 2008) were low, often below the detection limit of $1 \mathrm{mg} \cdot \mathrm{kg}^{-1}$.

In years 2 and 3, soil samples were collected on 01 May 2009 and 11 May 2010 (initial for season) and on 15 Oct. 2009 and 21 Sept. 2010 (end of season). Six cores were sampled from the tree row throughout each plot at three separate depths $(0-30,30-60$, and $60-90 \mathrm{~cm}$ ) and composited to characterize the soil N profile. During each growing season, soils were sampled by collecting and compositing six $0-30 \mathrm{~cm}$ cores from the tree row biweekly from 1 May 2009 through 30 Sept. 2009 and 10 May 2010 through 25 Sept. 2010. Beginning 25 May 2009, one anion-only PRS (plant root simulator) probe (Western $\mathrm{Ag}$ Innovations, Saskatoon, Canada) was placed in the middle of each plot within the tree row and these were collected and replaced biweekly when soil samples were collected. This was repeated from 11 May 2010 through 25 Sept. 2010. PRS probes were extracted with $20 \mathrm{~mL} 0.5 \mathrm{~N} \mathrm{HCl}$ (Qian and Shoenau, 2002) and the extract analyzed for $\mathrm{NO}_{3}-\mathrm{N}$ colorimetrically using the same technique and equipment used for soil $\mathrm{KCl}$ extracts.

"Mineralization tubes" (Hook and Burke, 1995; Raison et al., 1987) were used to develop a coarse estimate of mowed residue mineralization in the field. Tubes of ABS plastic pipe ( $7.5 \mathrm{~cm}$ I.D., $25 \mathrm{~cm}$ long) were driven $20 \mathrm{~cm}$ into the soil in the tree row on 14 July 2010 in the alfalfa and grass plots only. Two tubes (adjacent) were placed in each alfalfa plot, and one in each grass plot. Soil samples were collected from inside each tube using a $1.2 \mathrm{~cm}$ I.D. soil probe to $15 \mathrm{~cm}$ depth. Fresh alfalfa residue was added to one of the two paired tubes in the alfalfa plots at a rate similar to what the mow and blow would deliver to the tree row, whereas no residue was put in the other tubes. All tubes were capped to prevent leaching, and residue and soil inside each tube was kept moist (water was added to maintain $\approx 80 \%$ of field capacity). A soil core was collected from each tube every seven days over three weeks, resulting in a total of four sampling dates. Soil samples were air-dried, extracted, and analyzed for $\mathrm{NO}_{3}-\mathrm{N}$ using the same techniques as previous soil samples. Samples of alfalfa residue similar to what was put in tubes were weighed, dried, ground, and analyzed for total $\mathrm{N}$ as abovementioned, to determine the actual quantity of $\mathrm{N}$ in the initial residue in each tube. Percent $\mathrm{N}$ mineralized was calculated as follows: [(increase in $\mathrm{NO}_{3}-\mathrm{N}$ in alfalfa tube with residue-increase in $\mathrm{NO}_{3}-\mathrm{N}$ in alfalfa tube without residue)/total $\mathrm{N}$ in residue added to the tube $] \times 100$. No adjustments were made for other factors such as potential priming effects.

Data were analyzed using analysis of variance and least significant difference with Statistix 9 software (Analytical Software, Tallahassee, FL) or SAS software (SAS Institute, Cary, NC).

\section{Results and Discussion}

Legume stand. All four legume species germinated successfully with direct seeding (Granatstein et al., 2013). By mid-Aug. 2008, ladino clover reached $83 \%$ groundcover, followed by alfalfa at $71 \%$, trefoil at $49 \%$, and kura clover at 27\% (Table 1). Kura clover is known to be slow to establish as it puts most of its growth energy into its rhizomatous root system the first year which enables it to slowly spread and persist in subsequent years (Albrecht, 2000). Longevity for kura clover has been reported at 15-20 years, longer than the other species tested, and similar to the lifespan of many modern orchard plantings. Alfalfa tended to grow erect with little branching and had significantly more bare ground on some dates than the other legumes. The low spreading growth habit of the ladino clover appeared able to potentially complement that of alfalfa and a seeding mix of the two species would be useful to evaluate. In 2009, alfalfa and ladino clover had the numerically highest percent legume cover averaged over the season, whereas kura clover was significantly lower (Table 1). By 2010, there were no significant differences in percent cover among species on any of the measurement dates. The ladino clover stand declined significantly in 2010, whereas kura clover percent cover gradually increased over the three years and ended 2010 not significantly different from the other legume species.

Cover crop biomass and nitrogen content. In 2008, aboveground biomass (hereafter referred to as biomass) was not significantly different among cover crops (Fig. 1). However, this was the year of establishment and reflects a single mowing operation. In 2009, alfalfa had the greatest biomass, whereas kura had the lowest. The increasing biomass of kura clover above the preceding year was the most evident trend over time, which was expected because this species is known to partition more of its resources to the root system in the initial year, rather than to aboveground biomass (Albrecht, 2000). Trefoil showed a similar trend. Over the threeyear period, alfalfa and trefoil had similar total dry biomass, 2448 and $2513 \mathrm{~kg} \cdot \mathrm{ha}^{-1}$, whereas ladino clover, kura clover, and grass were significantly $(P<0.05)$ lower with biomass of 1935,1843 , and $2034 \mathrm{~kg} \cdot \mathrm{ha}^{-1}$, respectively. Alfalfa provided the most biomass $\mathrm{N}$ over the three years, given its higher yields and $\mathrm{N}$ concentration. By contrast, the low $\mathrm{N}$ concentration of grass led to numerically lowest biomass $\mathrm{N}$.

The legume cover crops had consistently higher biomass $\mathrm{N}$ content than the original grass/weed vegetation (Fig. 1). The lower N

Table 1. Average percent cover for legumes planted in 2008 in the orchard alley determined by point intercept. Means with the same letter are not significantly different using least significant difference $(P<0.05)$.

\begin{tabular}{llcc}
\hline & $2008^{\mathrm{z}}$ & \multicolumn{1}{c}{2009} & 2010 \\
\hline Alfalfa & $71.3 \mathrm{abc}$ & $70.0 \mathrm{abc}$ & $64.9 \mathrm{abcd}$ \\
Ladino clover & $83.3 \mathrm{a}$ & $77.7 \mathrm{ab}$ & $54.9 \mathrm{~cd}$ \\
Trefoil & $49.2 \mathrm{~d}$ & $59.7 \mathrm{bcd}$ & $61.5 \mathrm{bcd}$ \\
Kura clover & $27.1 \mathrm{e}$ & $45.4 \mathrm{de}$ & $57.8 \mathrm{bcd}$ \\
& Legume & Year & Legume $\times$ year \\
$P$ & 0.0001 & 0.5443 & 0.0124 \\
\hline
\end{tabular}

${ }^{\mathrm{z}}$ Measurement from 12 Aug. 2008 only. 
content in the kura clover can be attributed to poor stand establishment, lower $\mathrm{N}$ concentration in the kura than the other legumes, and the concomitant presence of more low-N vegetation in the sample. Biomass $\mathrm{C}: \mathrm{N}$ was significantly greater in May 2009 than for the later sampling dates and ranged from a season average high of 18.5 for grass to a low of 11.2 and 10.8 for ladino clover and alfalfa, respectively, which were similar to those from 2008. In 2009 and 2010, total N concentration was significantly different by the interactive factor of cover crop and sample date, but there was no consistent pattern (data not shown).

Alfalfa delivered the most biomass $\mathrm{N}$ per hectare of orchard during the study, with a high of $43 \mathrm{~kg} \cdot \mathrm{ha}^{-1}$ in 2009 (Fig. 1). Neilsen and Neilsen (2003) report that 30-100 $\mathrm{kg} \cdot \mathrm{ha}^{-1}$ is the annual $\mathrm{N}$ requirement for a mature bearing apple orchard. Our findings indicate that the legume can meet a meaningful portion of this requirement, and with a wider strip, enough available $\mathrm{N}$ to supply half of the orchard need might be generated as found in a subsequent study (Pavek and Granatstein, 2016) where alfalfa biomass contained up to $180 \mathrm{~kg} \cdot \mathrm{ha}^{-1} \mathrm{~N}$ in a mature apple orchard using a wider strip.

In this study, the biomass calculation was based on the width of the legume stand in the plot, which was generally less than the original planting width because of the effect of the tractor tires. This likely underestimated the total potential biomass, and total $\mathrm{N}$, delivered to the tree row during a mow and blow operation. In this study, it was not possible to plant the entire alley because of tree branch interference, thus the legume stand was generally one-third of the total alley width. However, if the entire alley had been planted, the total biomass could have been twice or more than what we reported, as was done in an adjacent orchard block of newly grafted trees. The values reported can be adjusted proportionally for orchards where a wider planting strip is possible.

These results show that a perennial legume intercrop can be successfully directseeded into established orchard alley sod and provide an $\mathrm{N}$ input to the orchard that can help meet part of the nitrogen needs of the trees. The persistence of these perennial species over time is an important consideration for growers who do not want to continually reseed the cover crop. By 2010, the ladino clover stand had already declined (Table 1), although the biomass increased and it still provided greater biomass $\mathrm{N}$ than the grass control (Fig. 1). It is not clear whether this particular strain of white clover has a shorter life than the low-growing white clovers that volunteer in orchards in the region. Testing of different strains and varieties of white clover would be useful because the species appears to be well-adapted to the orchard, particularly the shaded conditions.

Soil nitrogen. An initial soil test for available $\mathrm{N}$ in April 2008 before imposing the treatments evaluated site uniformity using composite samples for each block, and compared
0-15 and 15-30 cm depths in both the drive alley and tree row. Both nitrate and ammonium were significantly higher in the surface soil at all locations. There were no differences in nitrate between drive alley and tree row. There was also no obvious enrichment of nitrate in the drive alley when comparing grass, alfalfa, or ladino clover after planting (data not shown).

In 2009 and 2010, soils were sampled in the tree row in the spring (May) and autumn (October) at three depths $(0-30,30-60$ and $60-90 \mathrm{~cm}$ ) to evaluate plant available $\mathrm{N}$ $\left(\mathrm{NO}_{3}-\mathrm{N}\right)$ movement. Soil $\mathrm{NO}_{3}-\mathrm{N}$ concentration was significantly different with the main effects year, month and depth, but not crop $(P=0.0001,0.0001,0.0001$, and 0.4583 , respectively). Interactive factors crop by year and crop by month were not significant $(P=0.7870$ and 0.5428$)$, but both year by depth and crop by depth were significant $(P=0.0010$ and 0.0098$)$. Nitrate$\mathrm{N}$ was higher in May than in October, possibly as a result of the spring $\mathrm{N}$ fertilizer application. Soil $\mathrm{NO}_{3}-\mathrm{N}$ concentration also declined considerably from 2009 to 2010 , perhaps because of the fall $\mathrm{N}$ application in 2008 but not 2009 and was not higher under legume cover crops than under grass (Table 2).

Soil $\mathrm{NO}_{3}-\mathrm{N}$ was highest near the surface $(0-30 \mathrm{~cm})$ and declined with depth, suggesting minimal nitrate leaching. Within each depth, there were no significant nitrate differences among the cover crop treatments $(P=0.60)$.
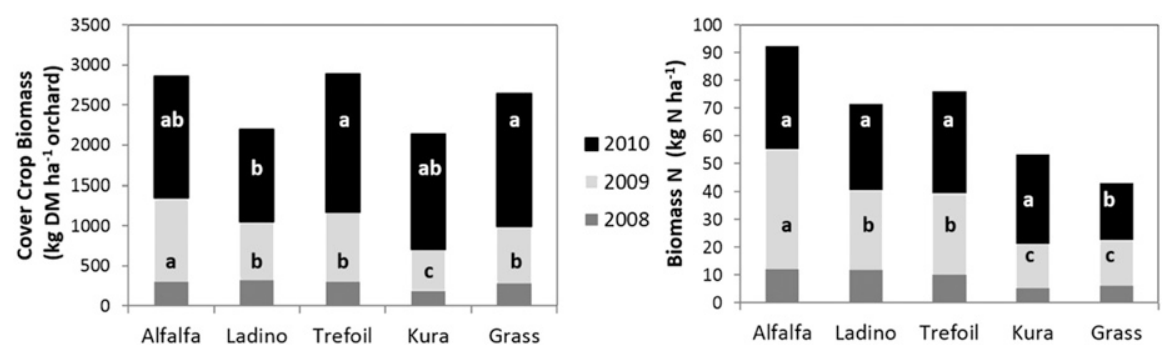

Fig. 1. Total seasonal cover crop biomass (left) and nitrogen content (right) in an apple orchard with four planted legume species compared with the original grass alley over three years. Means with the same letter for year are not significantly different $(P<0.05)$. There were no significant differences in 2008 , the year of establishment.

Table 2. Average soil $\mathrm{NO}_{3}-\mathrm{N}$ concentration in apple tree row, by depth, early and late in the second and third year (2009 and 2010, respectively) of cover crop establishment and mow and blow onto the tree row. Values with the same letter in the same column $(\mathrm{a}, \mathrm{b})$, or in the same row $(\mathrm{x}, \mathrm{y}, \mathrm{z})$ for each parameter are not significantly different $(P<0.05)$.

\begin{tabular}{|c|c|c|c|c|}
\hline & & \multicolumn{3}{|c|}{ Soil $\mathrm{NO}_{3}-\mathrm{N}\left(\mathrm{mg} \cdot \mathrm{kg}^{-1}\right)$} \\
\hline & & $0-30 \mathrm{~cm}$ & $30-60 \mathrm{~cm}$ & $60-90 \mathrm{~cm}$ \\
\hline \multirow[t]{2}{*}{ Year } & 2009 & $13.64 \mathrm{ax}$ & 6.38 ay & $5.16 \mathrm{az}$ \\
\hline & 2010 & $1.89 \mathrm{bx}$ & 0.99 by & $0.59 \mathrm{bz}$ \\
\hline \multirow[t]{2}{*}{ Month } & May & $13.18 \mathrm{ax}$ & 5.89 ay & $4.29 \mathrm{bz}$ \\
\hline & October & $2.34 \mathrm{bx}$ & 1.48 by & 1.46 by \\
\hline \multirow[t]{5}{*}{ Crop } & Kura Clover & $5.39 \mathrm{ax}$ & 3.036 ay & 2.49 ay \\
\hline & Ladino Clover & $9.70 \mathrm{ax}$ & 4.26 ay & $3.46 \mathrm{az}$ \\
\hline & Alfalfa & $9.40 \mathrm{ax}$ & 4.26 ay & $3.00 \mathrm{az}$ \\
\hline & Trefoil & 6.89 ax & 2.94 ay & 2.83 ay \\
\hline & Grass & $7.43 \mathrm{ax}$ & 3.93 ay & $2.60 \mathrm{az}$ \\
\hline \multirow[t]{4}{*}{$P$} & Year & 0.0001 & 0.0001 & 0.0001 \\
\hline & Month & 0.0001 & 0.0001 & 0.0001 \\
\hline & Crop & 0.6329 & 0.7348 & 0.8132 \\
\hline & Year * month & 0.0001 & 0.0002 & 0.0001 \\
\hline
\end{tabular}


the previous cover crop mow and blow event. Soil $\mathrm{NO}_{3}-\mathrm{N}$ concentration increased with time in the ABS tubes in plots from alfalfa and grass. Tubes with alfalfa residue had significantly higher nitrate- $\mathrm{N}$ than alfalfa plot tubes without residue only at $14 \mathrm{~d}$ after application. (Figs. 2 and 3) There was no significant difference in nitrate- $\mathrm{N}$ between the grass and alfalfa tubes without residue (bare) except for day 7, whereas alfalfa tube soils generally had higher numerical values.

The rate of $\mathrm{NO}_{3}-\mathrm{N}$ generation was calculated for each tube using linear regression, where the slope represents $m g \mathrm{NO}_{3}-\mathrm{N}$ per kg soil generated per day. The increase in $\mathrm{N}$ generation was significantly related to the addition of residue but not to cover crop, thus no difference between alfalfa vs. grass without the residue (Fig. 3). There was a 3 -fold increase in $\mathrm{N}$ release when the alfalfa residue was added. However, there was a decline in soil $\mathrm{NO}_{3}-\mathrm{N}$ concentration in the residue columns between day 14 and day 21 , indicating that the peak mineralization had been attained and the rate was declining for the alfalfa-amended treatment (Figs. 2 and 3). Mineralization continued in all columns which, in the case of the nonresidue-amended columns, could reflect mineralization from past added mow and blow materials. With only an estimated $7 \%$ of the nitrogen in the added alfalfa residue mineralized and measured in the soil over $21 \mathrm{~d}$, it is difficult to assess the effects of the treatments on long term mineralization. This is considerably lower than a previous estimate of $43 \%$ using the same method on another site with white clover (Mullinix and Granatstein, 2011). The clover may have been easier to degrade than the alfalfa because of clover having more leaves and less resistant stems. These findings clearly point to the need for further studies on $\mathrm{N}$ mineralization from surface applied residues.

Tree leaf mineral analysis. Tree leaf nitrogen was monitored in 2009 and 2010 because there was no mow and blow early enough in 2008 to precede the leaf sampling date (late July). There were no treatment effects in 2009 (Table 4), but these did appear by 2010 with leaf $\mathrm{N}$ elevated with alfalfa mow and blow compared with grass and kura $(P<0.10)$, with ladino and trefoil intermediate between alfalfa and grass. Leaf $\mathrm{N}$ was slightly lower than optimal in 2009 but within the low end of the optimal range in 2010 (Righetti et al.,1998) despite the decline in soil nitrate values. However, there are many factors that influence tissue $\mathrm{N}$ concentration in apple trees that could contribute to this finding (Neilsen and Neilsen, 2003).

A complete leaf mineral analysis in 2010 revealed a treatment impact on leaf boron, elevated by most legume treatments, but there were no treatment effects on any other minerals aside from $\mathrm{N}$ and $\mathrm{B}$ (data not shown). The small differences in $\mathrm{B}$ are unlikely of practical importance. In 2010, average leaf $\mathrm{P}$ and $\mathrm{K}$ were $0.28 \%$ and $2.29 \%$, respectively, and both are double the normal range of $0.14 \%$ and $1.2 \%$ (Righetti et al.,

Table 3. Differences in average soil $\mathrm{NO}_{3}-\mathrm{N}$ concentration by year and cover crop measured using traditional soil collection and monitoring with plant root simulator (PRS) ion exchange resins in an apple orchard where cover crops were mowed and the residue blown into the rows throughout the two growing seasons to supply N. Means with the same letter for year or crop are not significantly different $(P<0.05)$.

\begin{tabular}{cccc}
\hline & Parameter & Soil $_{3}-\mathrm{N}\left(\mathrm{mg} \cdot \mathrm{kg}^{-1}\right)$ & $\mathrm{PRS} \mathrm{NO}_{3}-\mathrm{N}\left(\mu \mathrm{g} \cdot \mathrm{mg}^{-1} 17.5 \mathrm{~cm}^{-2} \cdot \mathrm{week}^{-1}\right)$ \\
\hline Year & 2009 & $8.25 \mathrm{a}$ & $16.10 \mathrm{a}$ \\
& 2010 & $3.36 \mathrm{~b}$ & $10.58 \mathrm{~b}$ \\
Crop & $3.92 \mathrm{a}$ & $8.15 \mathrm{~b}$ \\
& Kura Clover & $7.72 \mathrm{a}$ & $15.19 \mathrm{a}$ \\
& Ladino Clover & $7.60 \mathrm{a}$ & $17.06 \mathrm{a}$ \\
& Alfalfa & $6.65 \mathrm{a}$ & $13.05 \mathrm{ab}$ \\
& Trefoil & $5.80 \mathrm{a}$ & $11.66 \mathrm{ab}$ \\
\hline
\end{tabular}

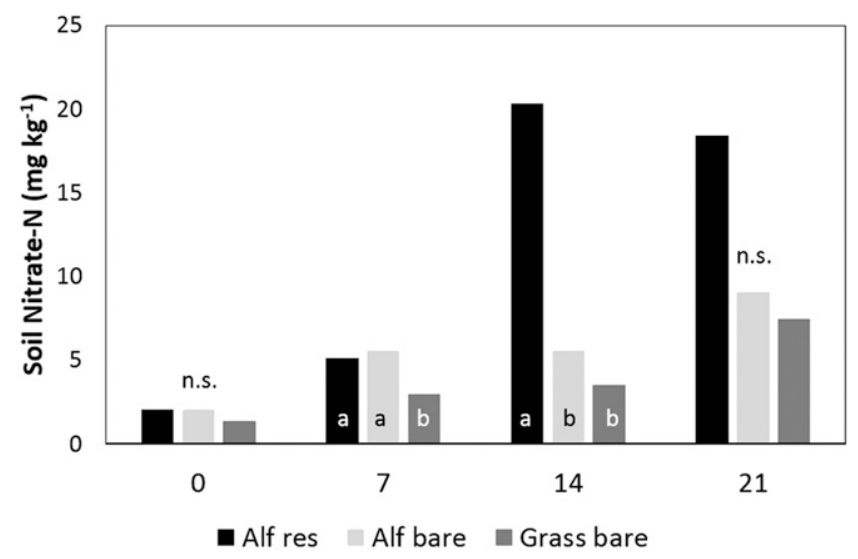

Fig. 2. Soil Nitrate-N within mineralization tubes in alfalfa (Alf) and grass plots. Res = tube with residue; bare $=$ tube with no residue. Bars with the same letter within a date are not significantly different $(P<0.05)$.

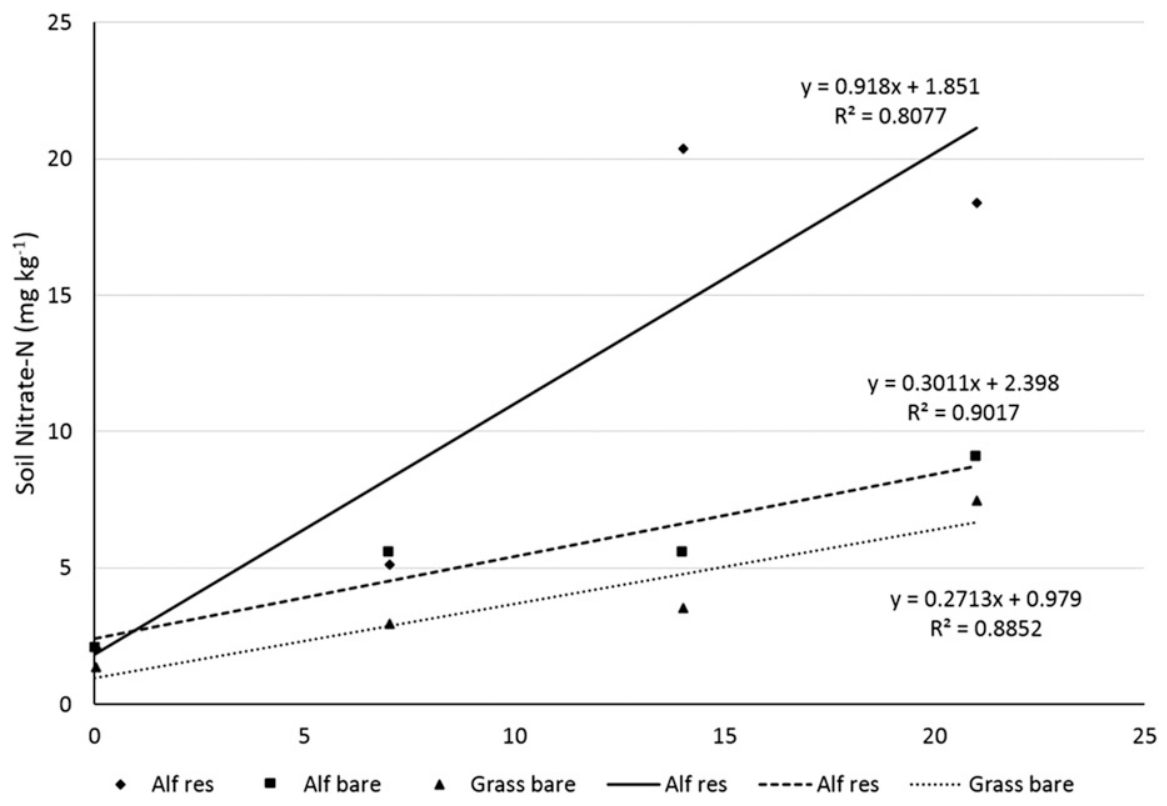

Fig. 3. Soil nitrate nitrogen concentration with and without alfalfa residue (residue and bare, respectively) from in situ soil columns in an apple orchard where alfalfa residue was added. Generalized linear model $P=0.0577$.

1998). This is consistent with the findings of Marsh et al. (1996) who found nutrient enrichment in apple tree soils with mow and blow management.
Economic estimates. The cost of establishing the legumes in the alleys was estimated from records from the cooperating grower, based on 2010 prices. Costs were 
Table 4. Selected tree leaf minerals affected by legume treatment, 2009 and 2010. Means with the same letter in a column are not significantly different $(P<0.10)$

\begin{tabular}{lcccc}
\hline & \multicolumn{2}{c}{ Nitrogen $(\%)$} & & Boron $\left(\mathrm{mg} \cdot \mathrm{kg}^{-1}\right)$ \\
\cline { 2 - 3 } \cline { 5 - 5 } Treatment & 2009 & 2010 & & 2010 \\
\hline Grass & 1.91 & $2.05 \mathrm{bc}$ & & $40.2 \mathrm{c}$ \\
Alfalfa & 1.95 & $2.14 \mathrm{a}$ & & $46.2 \mathrm{a}$ \\
Trefoil & 1.91 & $2.06 \mathrm{abc}$ & & $43.6 \mathrm{ab}$ \\
Ladino clover & 1.88 & $2.13 \mathrm{ab}$ & & $43.1 \mathrm{~b}$ \\
Kura clover & 1.91 & $2.04 \mathrm{c}$ & & $41.3 \mathrm{bc}$ \\
$P$ & 0.87 & 0.077 & & 0.004 \\
\hline
\end{tabular}

based on a $1.3 \mathrm{~m}$ planting width in the orchard alley and are presented per hectare of orchard treated. Costs included glyphosate to kill existing vegetation (\$17.66), tractor/ sprayer operation (\$36.68), tractor/seeder operation (\$73.36), and seed (\$79.00) for a total of \$207.23 per hectare. Assuming a legume stand would last for five years, the annual cost would be $\$ 41.45$ per ha. Average synthetic nitrogen fertilizer price in central Washington for 2006-10 was \$1.41 per kg N (N. Squires, personal communication). If the legume residue dry matter added $30 \mathrm{~kg} \mathrm{~N} / \mathrm{ha}$ each year for years $2-5$, this $120 \mathrm{~kg} \mathrm{~N}$ would be valued at $\$ 169 / \mathrm{ha}$, or $\$ 1.72$ per $\mathrm{kg} \mathrm{N}$. Although the legume $\mathrm{N}$ is roughly $20 \%$ more than commercial fertilizer $\mathrm{N}$, it is considerably less expensive than other sources of organic $\mathrm{N}$, which were selling at the time for $\$ 3$ (poultry waste) to $\$ 13$ (feathermeal) per $\mathrm{kg}$ of actual $\mathrm{N}$.

\section{Conclusions}

Direct seeding a legume cover crop into the existing vegetation of an orchard alley was successful. Alfalfa supplied the most N during the course of this study, whereas ladino clover appeared to have the shortest stand persistence. The ability to provide a significant $\mathrm{N}$ contribution will be influenced by the potential width of the legume planting; tractor traffic clearly reduced legume performance, but less so in ladino clover. In addition, a better understanding of surface applied crop residue mineralization is needed to more fully evaluate the actual
$\mathrm{N}$ contribution. The cover crops need adequate water for growth, and orchards with drip irrigation in dry climates may not provide enough water for these legumes. Also, careful water management is needed to conserve legume $\mathrm{N}$ as well as fertilizer $\mathrm{N}$. The amount of nitrogen made available at any one cutting appeared low enough to pose no risk for excess $\mathrm{N}$ at undesirable times of year, such as midsummer or late fall. Given that the legume germplasm used in this trial was originally developed for open-field forage production, further screening and selection of these and other species (Pavek and Granatstein, 2016) is needed to evaluate those traits which would optimize performance in an orchard setting, such as shade tolerance, tolerance to tractor traffic, and moderate spreading habit.

\section{Literature Cited}

Albrecht, K. 2000. Establishing kura clover stands. Univ. Wisconsin Extension, Madison, WI. 7 Apr. 2017. <http://www.uwex.edu/ces/forage/ pubs/Kura_stands.htm>.

Bair, K.E., J.R. Davenport, and R.G. Stevens. 2008. Release of available nitrogen after incorporation of a legume cover crop in concord grape. HortScience 43:875-880.

Barritt, B. 1992. Intensive orchard management. Good Fruit Grower, Wenatchee, WA. 211 p.

Camargo, G.T., M.R. Ryan, and T.L. Richard. 2013. Energy use and greenhouse gas emissions from crop production using the farm energy analysis tool. Bioscience 63:263-273.

Goh, K.M. and G.E. Ridgen. 1995. Understory biomass production and biological nitrogen fixation in an organic apple orchard in Canterbury, New Zealand. Commun. Soil Sci. Plant Anal. 26:3261-3273.

Granatstein, D., E. Kirby, and J.R. Davenport. 2013. Direct-seeding legumes into orchard alleys for nitrogen production. Acta Hort. 1001:329-334.

Granatstein, D. and E. Sanchez. 2009. Research knowledge and needs for orchard floor management in organic tree fruit systems. Intl. J. Fruit Sci. 9:257-281.

Hook, P.B. and I.C. Burke. 1995. Evaluation of methods for estimating net nitrogen mineralization in a semiarid grassland. Soil Sci. Soc. Amer. J. 59:831-837.

Marsh, K.B., M. Daly, and T.P. McCarthy. 1996. The effect of understory management on soil fertility, tree nutrition, fruit production and apple fruit quality. Biol. Agr. Hort. 13:161173.

Mullinix, K. and D. Granatstein. 2011. Potential nitrogen contributions from legumes in Pacific Northwest apple orchards. Intl. J. Fruit Sci. 11:74-87.

Mulvaney, R.L. 1996. Nitrogen - Inorganic forms, p. 1123-1184. In: J.M. Bigham (ed.). Methods of soil analysis part 3: Chemical methods. No. 5 in Soil Sci. Soc. Amer. Book Series. Madison, WI.

Neilsen, G.H. and D. Neilsen. 2003. Nutritional requirements of apple, p. 267-302. In: D.C Ferree and I.J. Warrington (eds.). Apples: Botany, production, and uses. CABI Publ., Cambridge, MA.

Pavek, P. and D.M. Granatstein. 2016. Legume cover in orchard drive alleys final report. No. 12864, USDA-NRCS Plant Materials Center, Pullman, WA. 53 p. <https://www.nrcs.usda.gov/ Internet/FSE_PLANTMATERIALS/publications/ wapmcsr12864.pdfs

Proebsting, E.L., Jr. 1958. Yield, growth, and date of maturity of Elberta peaches as influenced by soil management system. Proc. Amer. Soc. Hort. Sci. 72:92-101.

Qian, P. and J.J. Shoenau. 2002. Practical applications of ion exchange resins in agriculture and environmental soil research. Can. J. Soil Sci. 76:191-194.

Raison, R.J., M.J. Connell, and P.K. Khanna. 1987. Methodology for studying fluxes of soil mineral N in situ. Soil Biol. Biochem. 19:521-530.

Righetti, T., K. Wilder, R. Stebbins, D. Burkhart, and J. Hart. 1998. Nutrient management guide: Apples. Oregon State University EM8712, Corvallis, OR.

Sanchez, E.E., A. Giayetto, L. Cichon, D. Ferńandez, M.C. Arnani, and M. Curetti. 2006. Cover crops influence soil properties and tree performance in an organic apple (Malus domestica Borkh) orchard in northern Patagonia. Plant Soil 292:193-203.

Soltanpour, P.N., G.W. Johnson, S.M. Workman, J.B. Jones, Jr., and R.O. Miller. 1996. Inductively coupled plasma emission spectrometry and inductively coupled plasma-mass spectrometry, p. 91-140. In: J.M. Bigham (ed.) Methods of soil analysis part 3: Chemical methods. No. 5 in Soil Sci. Soc. Amer. Book Series. Madison, WI.

Yeomans, J.C. and J.M. Bremner. 1991. Carbon and nitrogen analysis of soils by automated combustion techniques. Commun. Soil Sci. Plant Anal. 22:843-850. 